\title{
Article
}

\section{Cigarette Smoke Condensate Exposure Induces Receptor for Advanced Glycation End-Products (RAGE)-Dependent Sterile Inflammation in Amniotic Epithelial Cells}

\author{
Helena Choltus ${ }^{1}\left(\mathbb{D}\right.$, Régine Minet-Quinard ${ }^{1,2}$, Corinne Belville ${ }^{1}$, Julie Durif ${ }^{2}$, Denis Gallot ${ }^{3}$, Loic Blanchon ${ }^{1}$ \\ and Vincent Sapin $1,2, *$ \\ 1 CNRS, INSERM, GReD, Université Clermont Auvergne, 63000 Clermont-Ferrand, France; \\ helena.choltus@uca.fr (H.C.); rquinard@chu-clermontferrand.fr (R.M.-Q.); corinne.belville@uca.fr (C.B.); \\ loic.blanchon@uca.fr (L.B.) \\ 2 CHU de Clermont-Ferrand, Biochemistry and Molecular Genetic Department, \\ 63000 Clermont-Ferrand, France; j_durif@chu-clermontferrand.fr \\ 3 CHU de Clermont-Ferrand, Obstetrics and Gynecology Department, 63000 Clermont-Ferrand, France; \\ denis.gallot@uca.fr \\ * Correspondence: vincent.sapin@uca.fr; Tel.: +33-4731-781-74
}

\section{check for} updates

Citation: Choltus, H.; Minet-Quinard R.; Belville, C.; Durif, J.; Gallot, D.; Blanchon, L.; Sapin, V. Cigarette Smoke Condensate Exposure Induces Receptor for Advanced Glycation End-Products (RAGE)-Dependent Sterile Inflammation in Amniotic Epithelial Cells. Int. J. Mol. Sci. 2021, 22, 8345. https://doi.org/10.3390/ ijms22158345

Academic Editor: Masashi Tanaka

Received: 1 July 2021

Accepted: 31 July 2021

Published: 3 August 2021

Publisher's Note: MDPI stays neutral with regard to jurisdictional claims in published maps and institutional affiliations.

Copyright: (c) 2021 by the authors. Licensee MDPI, Basel, Switzerland. This article is an open access article distributed under the terms and conditions of the Creative Commons Attribution (CC BY) license (https:/ / creativecommons.org/licenses/by/ $4.0 /)$.

\begin{abstract}
Maternal smoking is a risk factor of preterm prelabor rupture of the fetal membranes (pPROM), which is responsible for $30 \%$ of preterm births worldwide. Cigarettes induce oxidative stress and inflammation, mechanisms both implicated in fetal membranes (FM) weakening. We hypothesized that the receptor for advanced glycation end-products (RAGE) and its ligands can result in cigarette-dependent inflammation. FM explants and amniotic epithelial cells (AECs) were treated with cigarette smoke condensate (CSC), combined or not with RAGE antagonist peptide (RAP), an inhibitor of RAGE. Cell suffering was evaluated by measuring lactate dehydrogenase (LDH) mediumrelease. Extracellular HMGB1 (a RAGE ligand) release by amnion and choriodecidua explants were checked by western blot. NF- $\mathrm{BB}$ pathway induction was determined by a luciferase gene reporter assay, and inflammation was evaluated by cytokine RT-qPCR and protein quantification. Gelatinase activity was assessed using a specific assay. CSC induced cell suffering and HMGB1 secretion only in the amnion, which is directly associated with a RAGE-dependent response. CSC also affected AECs by inducing inflammation (cytokine release and NFKB activation) and gelatinase activity through RAGE engagement, which was linked to an increase in extracellular matrix degradation. This RAGE dependent CSC-induced inflammation associated with an increase of gelatinase activity could explain a pathological FM weakening directly linked to PPROM.
\end{abstract}

Keywords: maternal smoking; fetal membranes; RAGE; pPROM

\section{Introduction}

Worldwide, between 15 and 20\% of pregnant women still smoke, even though smoking cigarettes is a well-known risk factor for preterm prelabor rupture of fetal membranes (pPROM). This obstetrical complication can lead to disaster for both the mother and her baby, such as chorioamnionitis or oligohydramnios, and it is responsible for $30 \%$ of preterm births [1-5]. How does maternal smoking induce pPROM? Current data support the hypothesis that pPROM is caused most often by the exacerbation of the same cellular and molecular mechanisms that lead to term rupture: apoptosis, oxidative stress, extracellular matrix degradation, senescence, and sterile inflammation. In vitro studies offer different possibilities for tabagism modelling. First, some studies use a specific component of cigarettes; for example, nicotine. A recent study highlighted the dosedependent impact of nicotine on maternal and fetal inflammatory responses in pregnant rats [6]. Moreover, two products allow the testing of cigarette smoke's impact regarding its whole composition [7]. The first, which samples the water-soluble compounds, is cigarette 
smoke extract (CSE), which is used primarily as an inducer of oxidative stress (OS) [8-13]. The second, cigarette smoke condensate (CSC), is obtained from a particular part of cigarette smoke. CSE has already shown that cigarette smoke induces OS, senescence, and apoptosis, and also activates a p38 MAPK inflammatory cell pathway in FM cells, mechanisms that are implicated in tissue weakening $[9,13]$. Bredeson et al. also demonstrated that CSE induces high-mobility group B1 (HMGB1) release, a protein that acts as an alarmin when it becomes extracellular and activates sterile inflammation [10]. Moreover, in vivo, CSE injections also induce senescence and inflammation (the release of interleukin in amniotic fluid) in mice [8]. CSC demonstrated that it can dysregulate gene expression (for example, those targeted by a retinoid pathway) in amniotic cells [14], but the available studies on CSC implications remain scarce.

To date, the signaling actors and pathways activated in these tissues by cigarette smoke exposure are poorly understood. Nevertheless, mounting evidence supports the role of the receptor for advanced glycation end-products (RAGE) in inflammatory diseases associated with tabagism. Tobacco smoke has been shown to initiate the non-enzymatic Maillard reaction, leading to the formation of advanced glycation end-products (AGEs), which are one of the main ligands of RAGE. Moreover, cigarette smoke exposure has also been associated in vivo with the release or overexpression of HMGB1 or S100 proteins (A6, A9) in lungs [15-19]. Most of all, the abortion of RAGE activity in mice and humans has been described as being associated with a decrease of cigarette smoke-induced inflammation in different tissues. This is the case at the pulmonary level [20-22], in cardiovascular diseases [23], and for intrauterine growth restriction (IUGR) syndrome in the obstetrical sphere [24]. RAGE is a $50 \mathrm{kDa}$ cell membrane receptor that is implicated in many cell responses, including inflammation from its interaction with alarmins (HMGB1 and AGEs). Following its engagement through ligand fixation, RAGE can activate many pro-inflammatory cell-signaling pathways, such as NFKB or MAPK [25,26]. All previous data led to our hypothesis that cigarette smoking, modeled by CSC use and focusing on RAGE activation, induces FM weakening by increasing sterile inflammation.

\section{Results}

\subsection{Cigarette-Smoke Condensate Induces a Danger Response in the Fetal Amnion and Its Cells}

The impact of CSC treatment on cell toxicity was evaluated in FM explants (dissociated amnion and choriodecidua) by measuring LDH release in culture media (Figure 1A). Here, CSC provoked significant cell toxicity (ratio of 2.9) only in the amnion layer. Further, the release of the alarmin HMGB1 was investigated, and here again, we noted the induction of such a release only in the amnion layer (ratio of 6.6) but not in the choriodecidua layer (ratio of 0.9) (Figure 1B). Considering these results, further investigation of what happens in the amnion after CSC exposure was conducted by focusing on amniotic epithelial cells (AECs), which are in direct contact with the amniotic fluid that contains cigarette metabolites. Therefore, for the entire amnion layer, we demonstrated that CSC induced amniotic cell LDH release (ratio of 2.0) (Figure 1C) and provoked the nuclear toward cytosolic HMGB1 translocation. Indeed, whereas the control (DMSO, dimethylsulfoxyde) exhibited classical HMGB1 nuclear localization, CSC-treated cells showed a cytosolic HMGB1 cloud, a key step in subsequent extracellular release (Figure 1D).

\subsection{RAGE Axis Actors Are Expressed in Primary Amniotic Epithelial Cells (pAECS)}

HMGB1 is a well-known ligand of RAGE, implicated both in pro-inflammatory processes. It was necessary to confirm the expression of RAGE axis actors, including RAGE itself, as well as three other proteins: TIR adaptor protein (TIRAP), Myeloid differentiation primary response 88 (MyD88), and Diaphanous-1. In fact, many studies have established that RAGE requires one of these intracellular adaptors to induce a cell signal [27-29]. As shown in Figure 2, the RT-PCR demonstrated the expression of RAGE and its three adaptors in pAECs (2A). Then, immunocytochemistry experiments (2B) confirmed the protein expression of these RAGE axis actors. Further, we can observe that RAGE is localized in the 
nuclei and at the cell membrane of pAECs, in accordance with its functions as a membrane receptor and as a regulator of DNA repair $[25,30]$.

A)

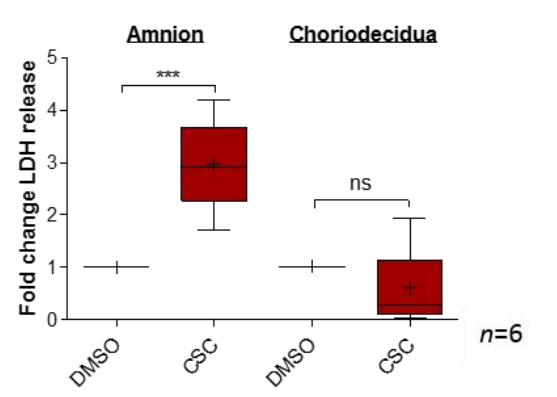

B)
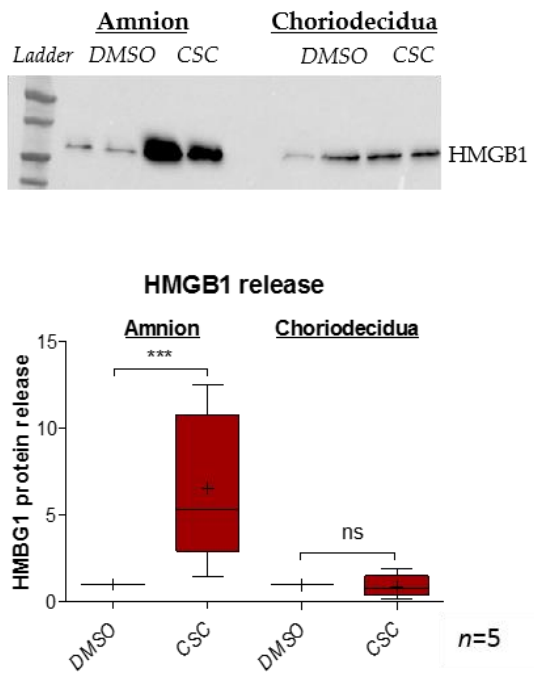

C)

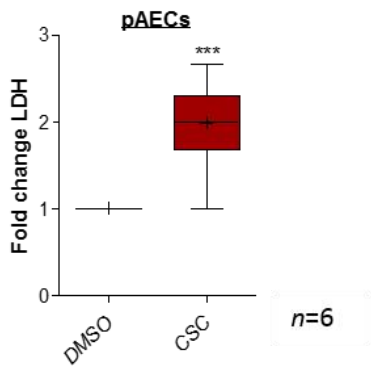

D)
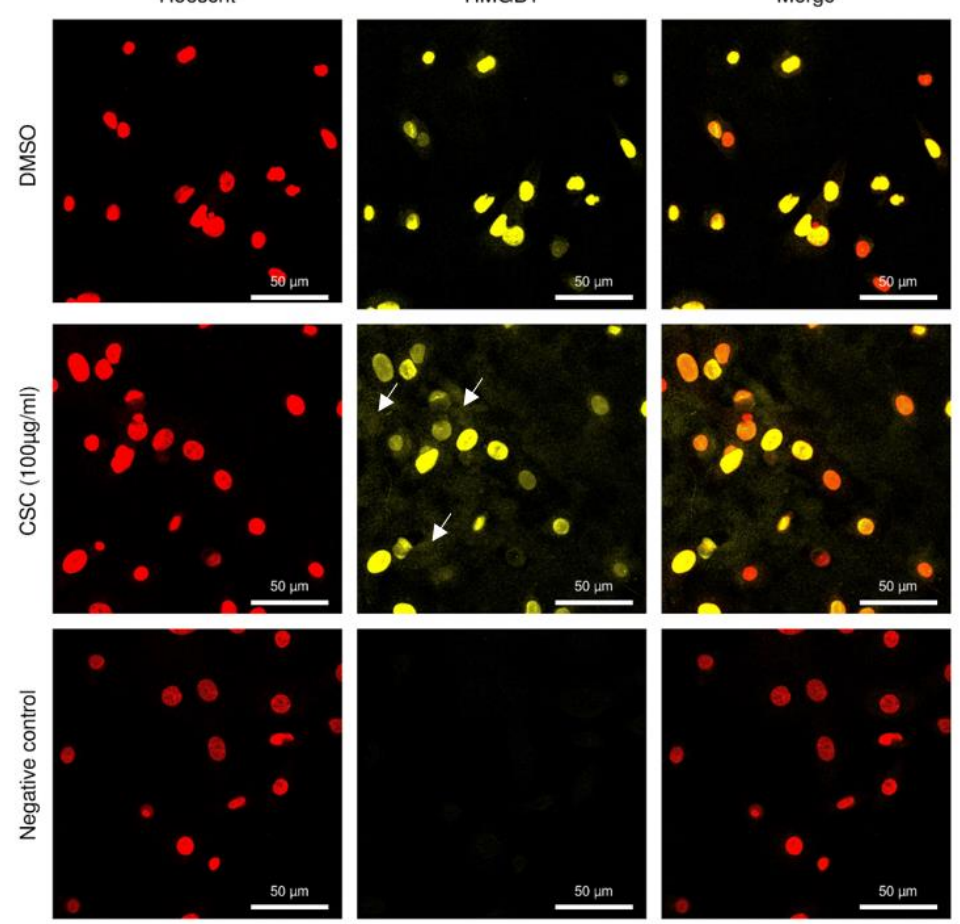

Figure 1. CSC treatment induces a cell danger response into amnion. (A) Cell toxicity was evaluated by measuring LDH release in a supernatant culture after a $24 \mathrm{~h}$ treatment with CSC in amnion and choriodecidua $(n=6)$. (B) HMGB1 release in a supernatant culture after a $48 \mathrm{~h}$ treatment with CSC was quantified by the western blot method in amnion and chori-odecidua; the results are reported in the histogram $(n=5)$. (C) Toxicity was evaluated by LDH release measurement in primary amniocytes (pAECs) cell-culture supernatants after a $48 \mathrm{~h}$ treatment with CSC $(100 \mu \mathrm{g} / \mathrm{mL})(n=6)$. (D) HMGB1 nuclear toward cytosolic translocation was investigated by immunocytochemistry on pAECs after $7 \mathrm{~h}$ treatment with CSC (yellow staining; Alexa488). Nuclei were counterstained with Hoechst (red). Scales bars: $50 \mu \mathrm{M}$ (magnification $\times 200$ ). Negative control was realized without primary antibody hybridization. White arrows indicate the cytosolic cloud of HMGB1. Comparison with the control (DMSO) was realized by a Mann-Whitney $t$-test. ${ }^{* * *}$ means $p<0.001$, and "ns" means "not significant". Results are presented in Tukey boxes; means are indicated by "+".

\subsection{Cigarette Smoke Condensate Induces RAGE Signaling Cascade in pAECs}

The pAECs were treated for $48 \mathrm{~h}$ with either only CSC or with a RAGE competitive inhibitor, RAP. RT-qPCR was performed on pAECs to quantify RAGE axis members' expression. The results revealed no impact on RAGE, Dia-1, or TIRAP expression. However, CSC significantly increased the Myd88 transcription level (ratio of 1.6), and this augmentation was lower in the case of co-treatment with RAP (ratio of 1.3) (Figure 3A). Yet, the NFKB luciferase reporter assay demonstrated that pAECs exposed to CSC activated the pro-inflammatory NFKB cell signaling (ratio of 2.4), which was aborted in the presence of 
RAP (ratio of 1.7) (Figure 3B). Furthermore, the immunofluorescence of p65 NFkB protein supported the idea that CSC activates this pathway by passing through the RAGE receptor. As described in the literature, control cells exhibited p65 localization mainly in cytosol (a cell compartment where p65 is mainly sequestered when there is no activation). Linked to the signal transduction by RAGE (blocked by RAP), the CSC treatment affected this localization with an addressing of $\mathrm{p} 65$ from the cytosol to the perinuclei/nuclei, which attests NFKB activation (Figure 3C).

A)

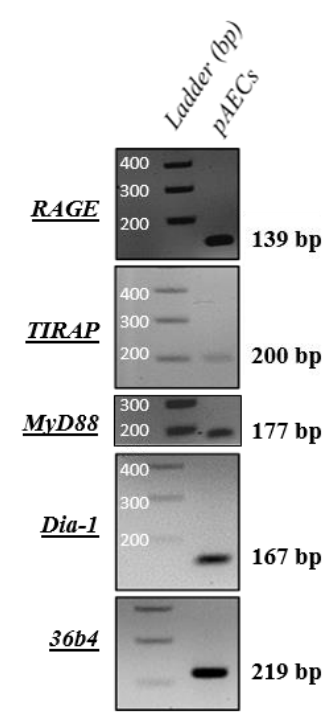

B)
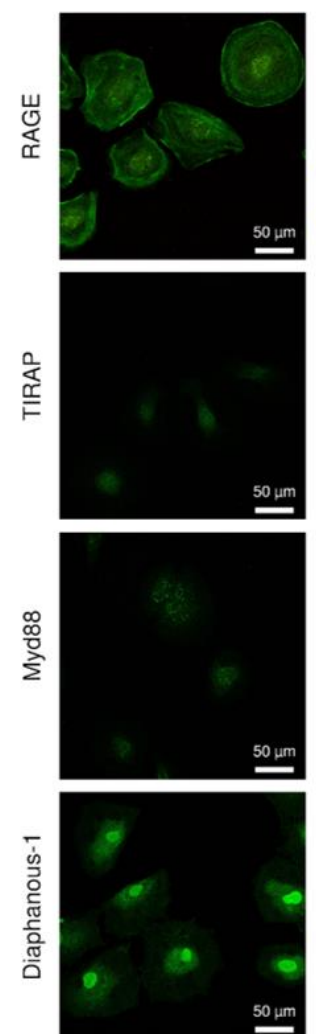

Hoechst
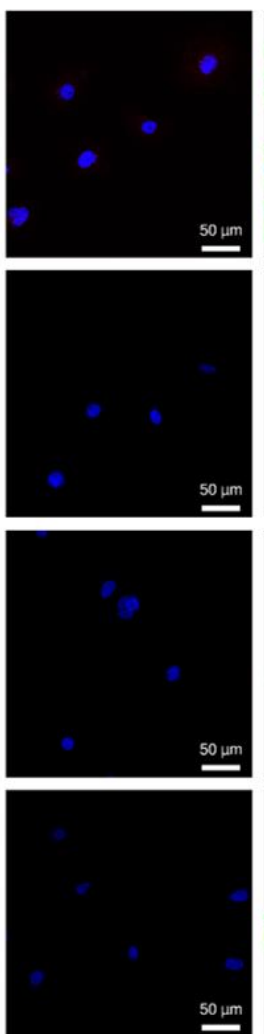

Merge
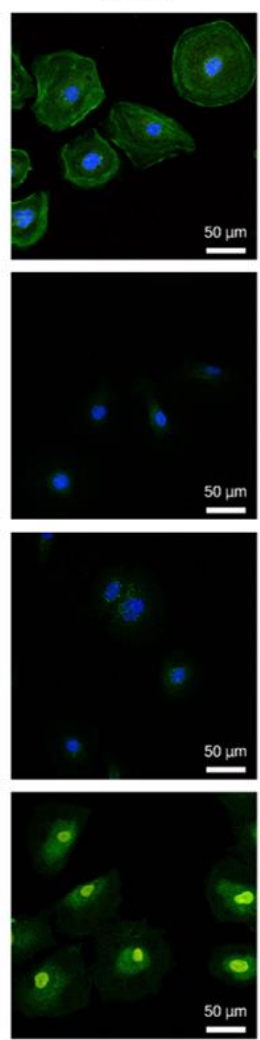

Negative control
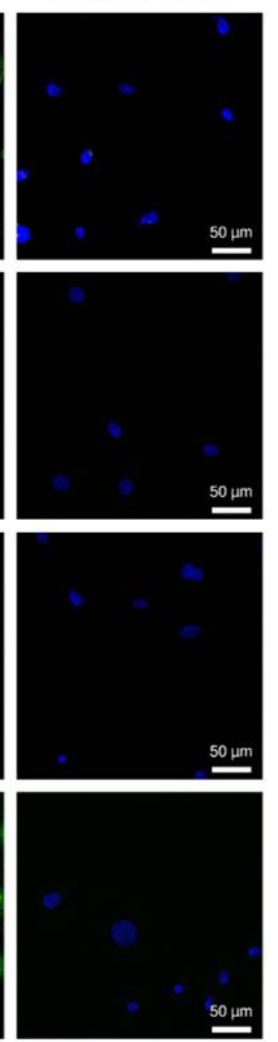

Figure 2. Amniotic epithelial cells expressed a functional RAGE axis. (A) RNA expressions of RAGE, TIRAP, Myd88, and Diaphanous-1 were detected by RT-PCR in pAECS. Negative controls were performed in the absence of a cDNA template. (B) The RAGE receptor and its adaptors, Diaphanous-1, MyD88, and TIRAP (green staining, Alexa488), were detected by immunocytochemistry on primary amniocytes (pAECs). Nuclei were counterstained with Hoechst (blue). Scales bars: $50 \mu \mathrm{M}$ (magnification $\times 200$ ). Negative control was realized without primary antibody hybridization.

\subsection{Cigarette Smoke Condensate Induces Pro-Inflammatory Response in pAECs}

As CSC engages the RAGE pathway, one of the most well-known consequences of RAGE activation to study is the increasing production of pro-inflammatory mediators, such as cytokines. In fact, transcription quantification of pro-inflammatory cytokines demonstrated a significant fold change induction of IL1 $\beta$ (ratio of 10.13), IL8 (ratio of 904.3), and IL6 (ratio of $291.10^{3}$ ), but not TNF $\alpha$ (data not shown), after CSC treatment. Above all, RAGE inhibition by RAP led to an abortion of IL8 induction (ratio of 45.1) and a smaller increase of IL6 expression (ratio of $142.10^{3}$ ), but it had no impact on the IL1 $\beta$ fold change (ratio of 13.33) (Figure 4A). The cytokines released by pAECs were investigated after 48 or $72 \mathrm{~h}$ of CSC treatment, using ELLA assays (Figure 4B). First, we observed that CSC provoked a release of IL1 $\beta$ (ratio of 2.0 at $48 \mathrm{~h}$ ), IL8 (ratio of 4.3 at $48 \mathrm{~h}$ and 13.6 at $72 \mathrm{~h}$ ), and IL6 (ratio of 2.7 at $72 \mathrm{~h}$ ). Second, these results confirmed the inhibitory effect of RAP on CSC inflammatory action (as obtained before) for IL8 (ratio of 6.1) and IL6 (ratio of 1.6) release at $72 \mathrm{~h}$, but also for IL1 $\beta$ at $48 \mathrm{~h}$ (ratio of 1.8). 
A)

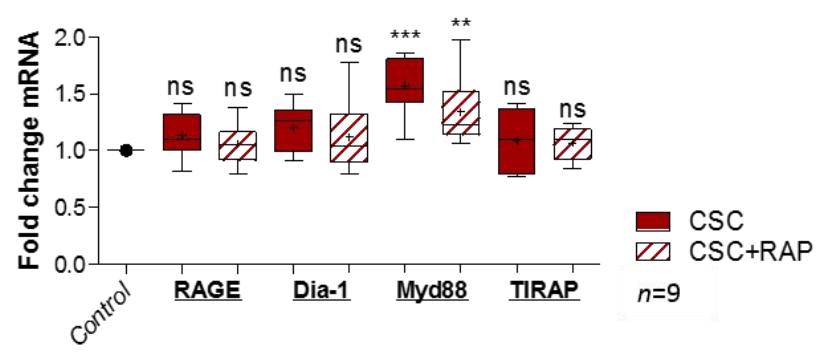

B)

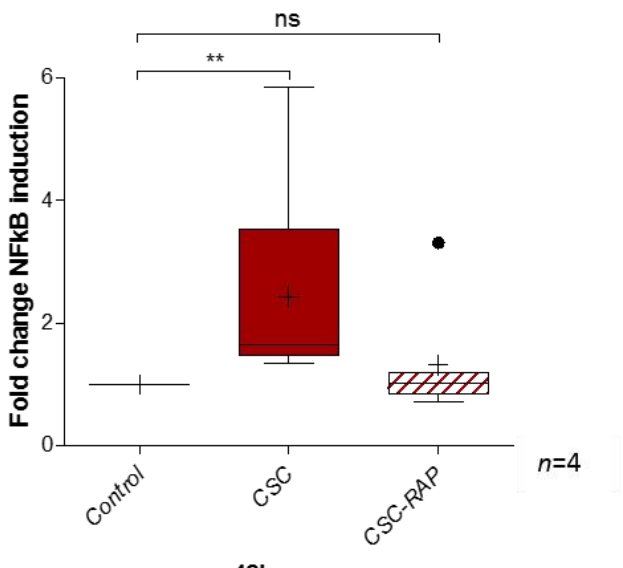

$48 \mathrm{~h}$
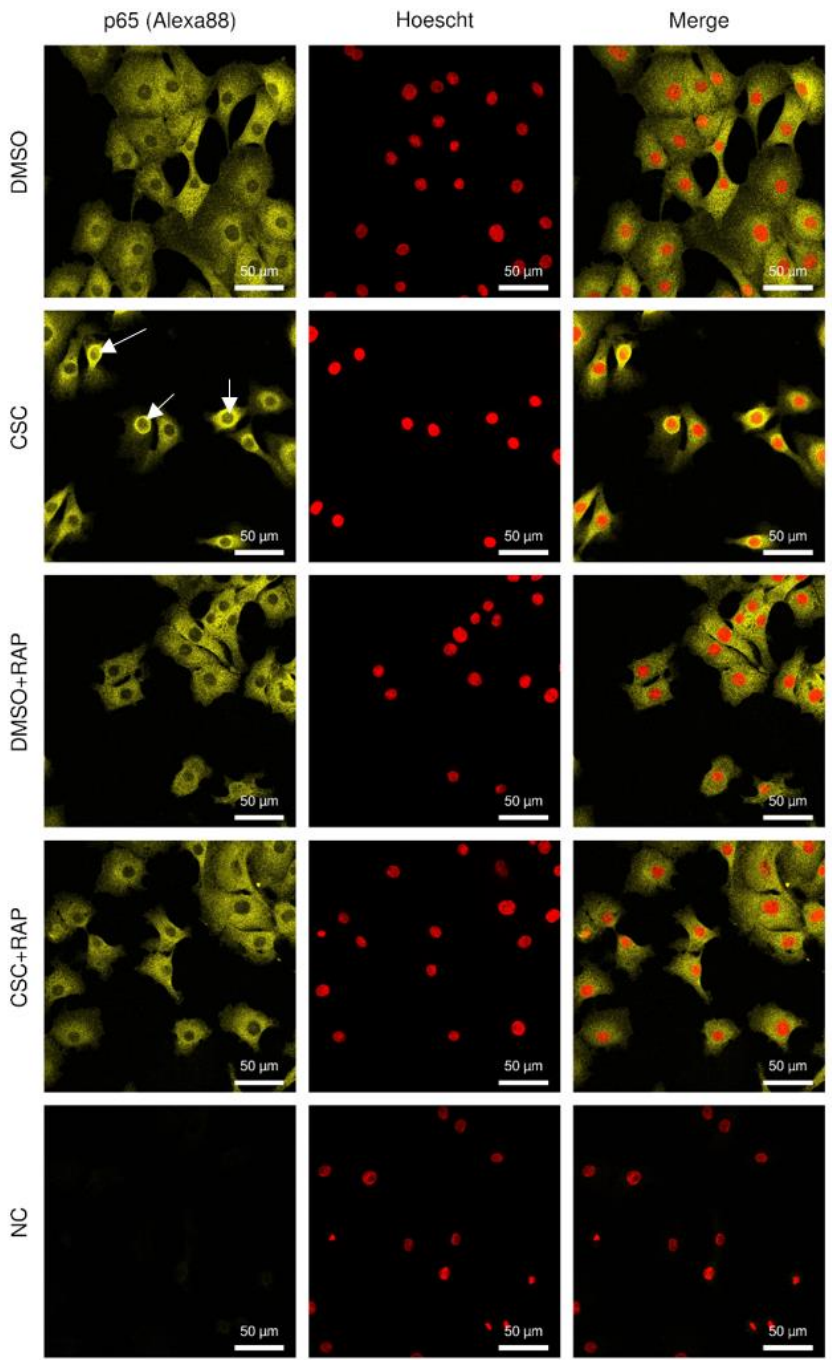

Figure 3. Activation of RAGE axis by CSC-response in pAECs. (A) Quantification of RAGE and its signaling adaptors (Diapahnous-1, Myd88, and TIRAP) transcription by RT-qPCR following $48 \mathrm{~h}$ of CSC $(100 \mu \mathrm{g} / \mathrm{mL})+/-\mathrm{RAP}(12.7 \mu \mathrm{g} / \mathrm{mL})$ treatment of pAECs $(n=7)$. (B) NFKB luciferase reporter assay was performed after $48 \mathrm{~h}$ of CSC treatment $(100 \mu \mathrm{g} / \mathrm{mL})$, whether combined or not with RAP $(12.7 \mu \mathrm{g} / \mathrm{mL})(n=4)$. (C) p65-NFkB relocalization was investigated by immunocytochemistry on pAECs, whether treated or not with CSC for $48 \mathrm{~h}$ (yellow staining; Alexa488). Nuclei were counterstained with Hoechst (red). Scales bars: $50 \mu \mathrm{M}$ (magnification $\times 200$ ). Negative controls were realized without primary antibody hybridization. White arrows indicate perinuclear/nuclear relocalization of the p65 protein. A comparison of conditions was realized by a Kruskal-Wallis one-way ANOVA test, followed by a Dunn's post-test. ${ }^{* *}$ means $p<0.01,{ }^{* * *}$ means $p<0.001$, and "ns" means "not significant". Results are presented in Tukey boxes, and means are indicated by "+".

FM integrity relies on an extracellular matrix (ECM) structure. Some proteins, such as the metalloproteases 2 and 9, exercise gelatinase activity, leading to ECM degradation. We investigated whether CSC treatment could have an impact on this by first modulating the transcription of MMP2 and MMP9, and then increasing gelatinase activity. The RTqPCR experiment revealed a significant induction of MMP9 expression (ratio of 8.5) by CSC at $48 \mathrm{~h}$, but no impact on the MMP2 expression level (ratio of 0.7) (Figure 5A). We also observed that RAP decreased MMP9 induction (ratio of 4.8) and diminished MMP2 expression compared to the control (ratio of 0.6). Then, the measurement of gelatinase activity after 48 or $72 \mathrm{~h}$ of CSC treatment, whether or not it was combined with RAP, revealed the induction of gelatinase activity at $72 \mathrm{~h}$, compared to the control (ratio of 1.14); this induction was suppressed in the presence of the RAGE inhibitor RAP (ratio of 0.94) (Figure 5B). 
A)

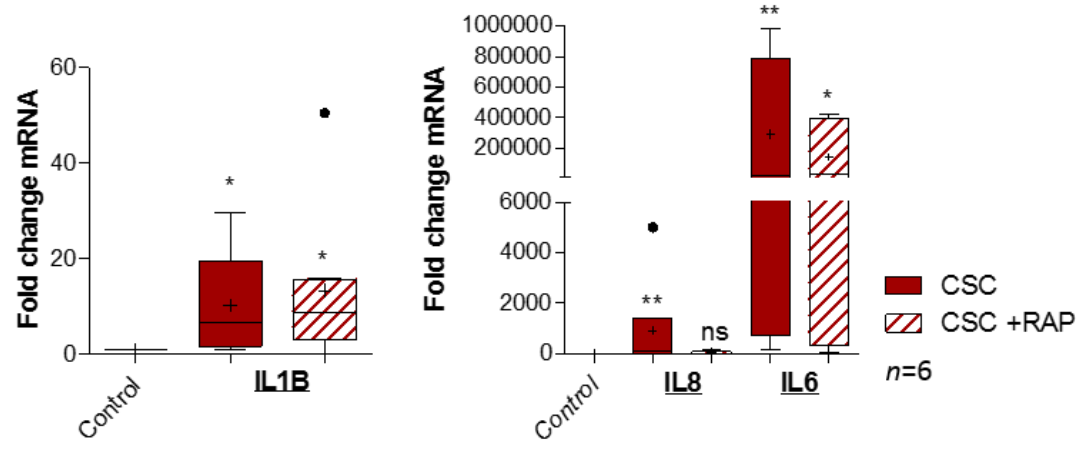

B)
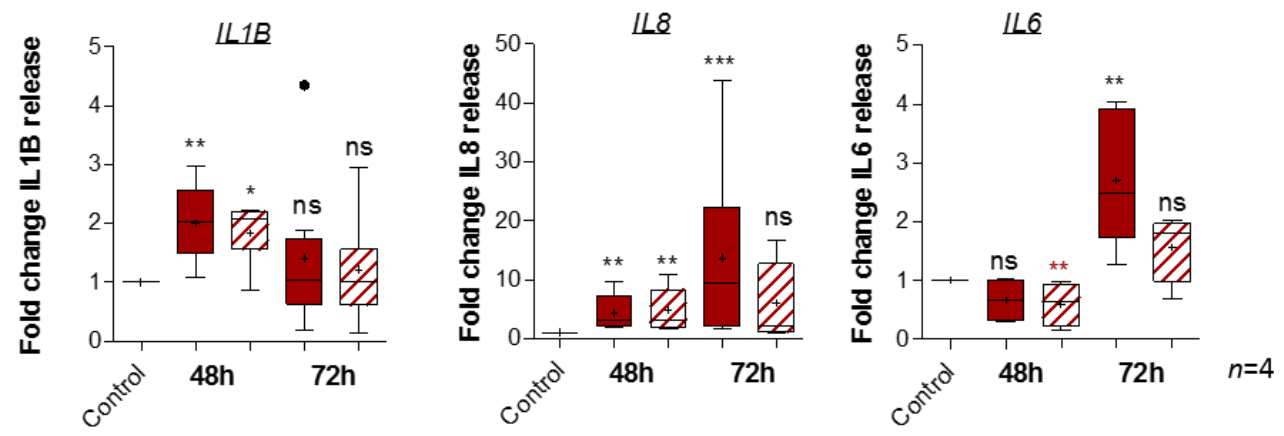

Figure 4. RAGE is implicated in CSC-induced pro-inflammatory cytokine production in pAECs. (A) Quantification of cytokine mRNA expression by RT-qPCR following $48 \mathrm{~h}$ of CSC $(100 \mu \mathrm{g} / \mathrm{mL})+/-\mathrm{RAP}(12.7 \mu \mathrm{g} / \mathrm{mL})$ treatment of pAECs $(n=6)$. (B) Pro-inflammatory cytokine (IL8, IL6, IL1 $\beta$ ) secretion was quantified by ELLA technology after 48 and $72 \mathrm{~h}$ (with $48 \mathrm{~h}$ re-treatment) of CSC treatment $(n=4)$. A comparison of conditions was realized by a Kruskal-Wallis one-way ANOVA test, followed by a Dunn's post-test. * means $p<0.05,{ }^{* *}$ means $p<0.01,{ }^{* * *}$ means $p<0.001$, and "ns" means "not significant". Cigarette Smoke Condensate Enhances Gelatinase Activity in pAECs through the RAGE Pathway.

A)

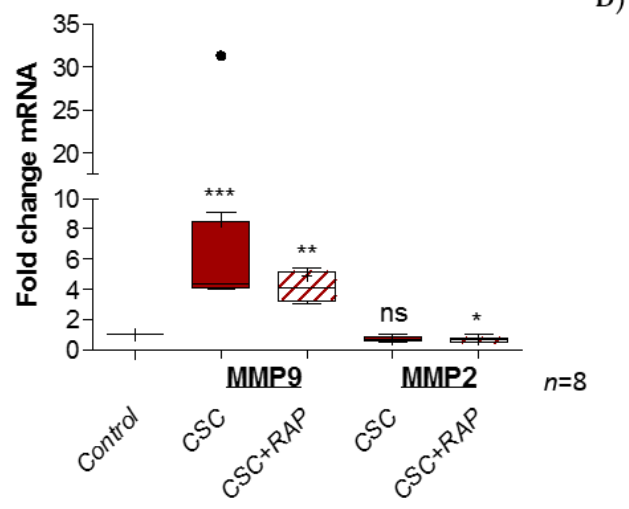

B)

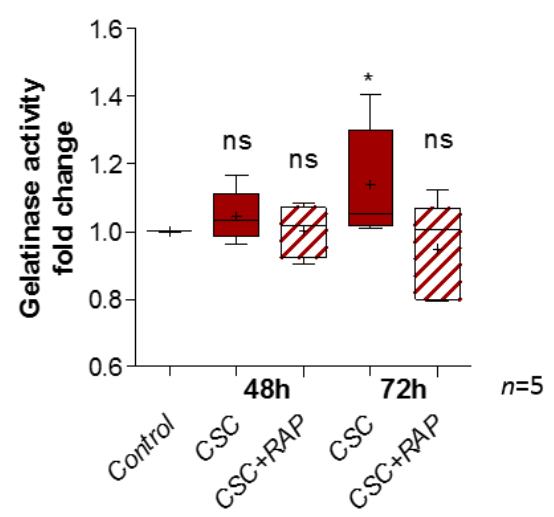

Figure 5. CSC exposure stimulates gelatinase activity in pAECs through the RAGE pathway. (A) Transcription of MMP2 and MMP9 gelatinases were measured by RT-qPCR into pAECS after $48 \mathrm{~h}$ of CSC treatment $(100 \mu \mathrm{g} / \mathrm{mL})$, whether combined or not with RAP $(12.7 \mu \mathrm{g} / \mathrm{mL})(n=8)$. (B) Gelatinase activity was studied by a zymography kit assay on pAECs cell media after 48 and $72 \mathrm{~h}$ (with $48 \mathrm{~h}$ re-treatment) of CSC treatment $(n=5)$. Statistical analysis was performed using a Kruskal-Wallis one-way ANOVA test, followed by a Dunn's post-test. * means $p<0.05,{ }^{* *}$ means $p<0.01$, ${ }^{* * *}$ means $p<0.001$, and "ns" means "not significant". Results are presented in Tukey boxes, and means are indicated by "+". Black dots indicate values outside of the Tukey boxes. 


\section{Discussion}

Many pathologies are caused by cigarette-induced sterile inflammation, which can lead to lung impairments (e.g., chronic obstructive pulmonary disease), cancer mechanisms (in lung, larynx, and pancreas), cardiometabolic abnormalities (e.g., atherosclerosis, dyslipidemia, hyperinsulinemia, and cardiomyopathy), as well as joint (osteoarthritis) or maternal-fetal disorders [2]. More and more studies highlight the implication of RAGE signaling in the establishment of sterile inflammatory diseases that are linked with exposure to primary and secondhand cigarette smoke. For many decades, it has been well known that cigarette smoking has deleterious effects on pregnancy outcomes, such as preterm births and pPROM [31-33]. The involvement of RAGE has already been described in IUGR development, and it is also well known that inflammation is implicated in physiopathological FM weakening. Surprisingly, only a few studies have investigated the cellular signaling actors responsible for cigarette-induced inflammation in PPROM pathogenesis. Nevertheless, it is important to underline that this inflammation is of a "sterile type", involving the release of alarmins, which could be recognized by the RAGE receptor. From this initial evidence, our work consisted of investigating whether RAGE was implied in FM weakening and whether this is a new link between maternal smoking and premature sterile inflammation.

Human FM are composed of two layers: the amnion and the choriodecidua. Our in vitro experiments identified a different response to CSC from each of these tissues. Indeed, we noticed a significant induction of cell toxicity and an induction of HMGB1 release only in the amnion. The choriodecidua did not seem to be sensitive to CSC treatment. This could be explained by the fact that in vivo cigarette compounds are classically accumulated in amniotic fluid and in direct contact with the amnion (particularly its epithelial cells), but this is not the case for the choriodecidua. Our work aimed to more precisely describe the inflammatory response activated by CSC at the cellular amniotic level. We demonstrated that cigarette smoke compounds induce cell toxicity and provoke a release of alarmins (HMGB1), which is associated with sterile inflammation in pAECs. The release of DAMPs has already been identified in other models (e.g., chronic obstructive pulmonary disease), where it is well established that cigarette smoke exposure can induce necrotic death in airway epithelial cells, provoking DAMP (HMGB1, AGEs, S100, HSP70, and dsDNA) accumulation in the extracellular space [18,34-36]. These DAMPs are recognized by pattern recognition receptors (PRRs), such as RAGE. The engagement of these receptors can lead to an inflammatory response through the activation of pro-inflammatory pathways, such as NFKB. RAGE expression has already been identified in human FM. Our team already reported that RAGE is overexpressed, not only in the amnion compared to choriodecidua, but also in the rupture zone compared to the intact one. In parallel, a previous study demonstrated that FM are sensitive to RAGE ligands: the AGEs and HMGB1 [37]. This preferential expression of RAGE in the amnion could be exacerbated by contact with smoking compounds, explaining such amniotic susceptibility to CSC.

RAGE is a transmembrane receptor implicated in many cell responses (e.g., apoptosis, proliferation, inflammation, and cell migration), but cannot act alone [25]. Indeed, RAGE is deficient in intrinsic activity and requires intracellular adaptors to induce cell-signaling cascades. In the literature, we found three major adaptor proteins that interacted with the RAGE cytosolic domain and were described in the inflammatory signal: TIRAP, MyD88 shared with the toll-like receptors TLR2 and TLR4, and Diaphanous-1 [28,29]. For the first time, RAGE and its three adaptors were identified in AECs. Interestingly, our work additionally revealed a significant overexpression of MyD88, a RAGE intracellular adaptor whose expression was decreased by RAGE inhibition. Some studies have already investigated the role of Myd88 regarding cellular consequences of smoking. For example, Myd88-dependent signaling regulates, at least partially, CS-induced inflammation in bronchial epithelial cells, supporting the role of RAGE [34]. Moreover, the Filipovich group demonstrated that knockout mice for MyD88 were protected against Escherichia coli-induced preterm delivery, proving the essential role of Myd88 in septic preterm de- 
livery, which allowed us to suppose that it could also be implicated in sterile cases of preterm birth [38]. Then, our work demonstrated that RAGE is required for the activation of NF- $\mathrm{KB}$, which is a pro-inflammatory pathway well-known for inducing the production of pro-inflammatory mediators, such as cytokines. NF- $\mathrm{kB}$ was already known to be implied in childbirth, since human labor is associated with a constant increase of NF- $\mathrm{kB}$ activity in the amnion [39]. Moreover, Sheller-Miller et al. demonstrated that the in vivo injection of an NF- $\mathrm{kB}$ inhibitor delays LPS-induced preterm delivery [40]. Thus, by its impact on this cell pathway, it seems that maternal smoking could provoke preterm birth by affecting other events of parturition (preterm labor) in addition to pPROM.

Finally, our work illustrated the downstream effects of this RAGE activation by CSC in pAECs following NF- $\mathrm{kB}$ activation. In this way, this study highlighted that CSCtreated pAECs exhibit higher levels of pro-inflammatory cytokine transcription and release (IL6, IL8, and IL1 $\beta$ ). In addition, RAGE inhibition led to the decrease of IL1 $\beta$ and the cessation of IL8 and IL6 release. This directly proves that cigarette smoke (CS) can induce inflammation through a RAGE pathway. However, the absence of a total abortion for IL1 $\beta$ release could suggest the intervention of other actors, such as the well-known TLR4, which can also interact with alarmins. For example, it was found that nicotine modulates the expression of TLR2/4 into cord blood mononuclear cells [41]. Cheng et al. also demonstrated that HMGB1 translocation can mediate CS-induced pulmonary inflammation through the TLR4/MyD88 pathway [42]. However, Allam et al. demonstrated that RAGE and TLR4 differentially regulate airway responsiveness to cigarette smoke (CS). Indeed, the authors used RAGE and TLR4 knockout mice and found that only RAGE deletion procured protection against CS-induced neutrophils and airway responsiveness [43]. In our amniotic context, we tested at the beginning of the project the impact of CSC on TLR4 expression and found that there is no induction (ratio 1.1 by qRT-PCR, Supplementary Data S1, See Supplementary Files) excluding the TLR4 hypothesis. Nevertheless, further studies are required to explore the potential cooperation between these two PRRs concerning sterile inflammation in FM.

Sterile inflammation is clearly associated with extracellular matrix (ECM) degradation, which is also a recurrent phenomenon that destructures tissue integrity, in fine, the FM weakening. The major actors in this ECM deterioration are enzymes called metalloproteinases. Two major groups comprise this family: gelatinases (MMP2 and 9) and collagenases (MMP1, 7, 8, and 13). Amniotic epithelium express MMP1, 2, and 9. Our work demonstrated that CSC stimulates MMP9 transcription in amniotic epithelial cells but has no impact on MMP2 and MMP1 (data not shown for MMP1). Moreover, the RAGE blockade led to a decrease in CSC-induced MMP9 expression and the physiological expression of MMP2. We also investigated gelatinase activity on cell supernatants by zymography assay. Here, we revealed an induction of gelatinase activity by CSC at $72 \mathrm{~h}$, and this induction was aborted by RAP treatment. In the literature, RAGE was implicated in CS-induced MMP expression and/or activity (MMP2, 9, and 14) in the respiratory tree [44]. Moreover, MMP9 was revealed to be increased in amniotic fluid and fetal plasma in the case of pPROM; thus, it is considered a potential biomarker of pPROM [45,46]. Polymorphism in the MMP9 promoter is associated with an increased risk of pPROM [47]. Finally, many studies have described the implication of NFKB pathway in MMP9 upregulation in the case of inflammation [48-51]. Our results revealed a new way in which CSC weakens FM through RAGE and is in total accordance with the results obtained in other tissues.

In conclusion, our work makes clear a way that cigarette smoking (CSC) can induce FM weakening and, in fine, a pPROM, as summarized in our RAGE-dependent model of action (Figure 6).

Indeed, we proved that CSC provokes a sterile inflammatory response in amnion epithelial cells by activating the RAGE pathway. This increase in inflammation may accelerate the physiological weakening of FM. Due to the complexity of the molecules, as well as the gas released during cigarette smoking, it would be interesting to compare the effects of CSC (the particular phase) to the effects of CSE (sampling the water-soluble 
compounds) and to check the activation and implication of RAGE pathways in such a mixed exposure case. Nevertheless, this study still supports a cellular explanation for the negative effects of tobacco smoke on pregnant women and paves the way for developing new preventive strategies to protect smoking mothers from $\mathrm{PPROM}$ by targeting the RAGE pathway.

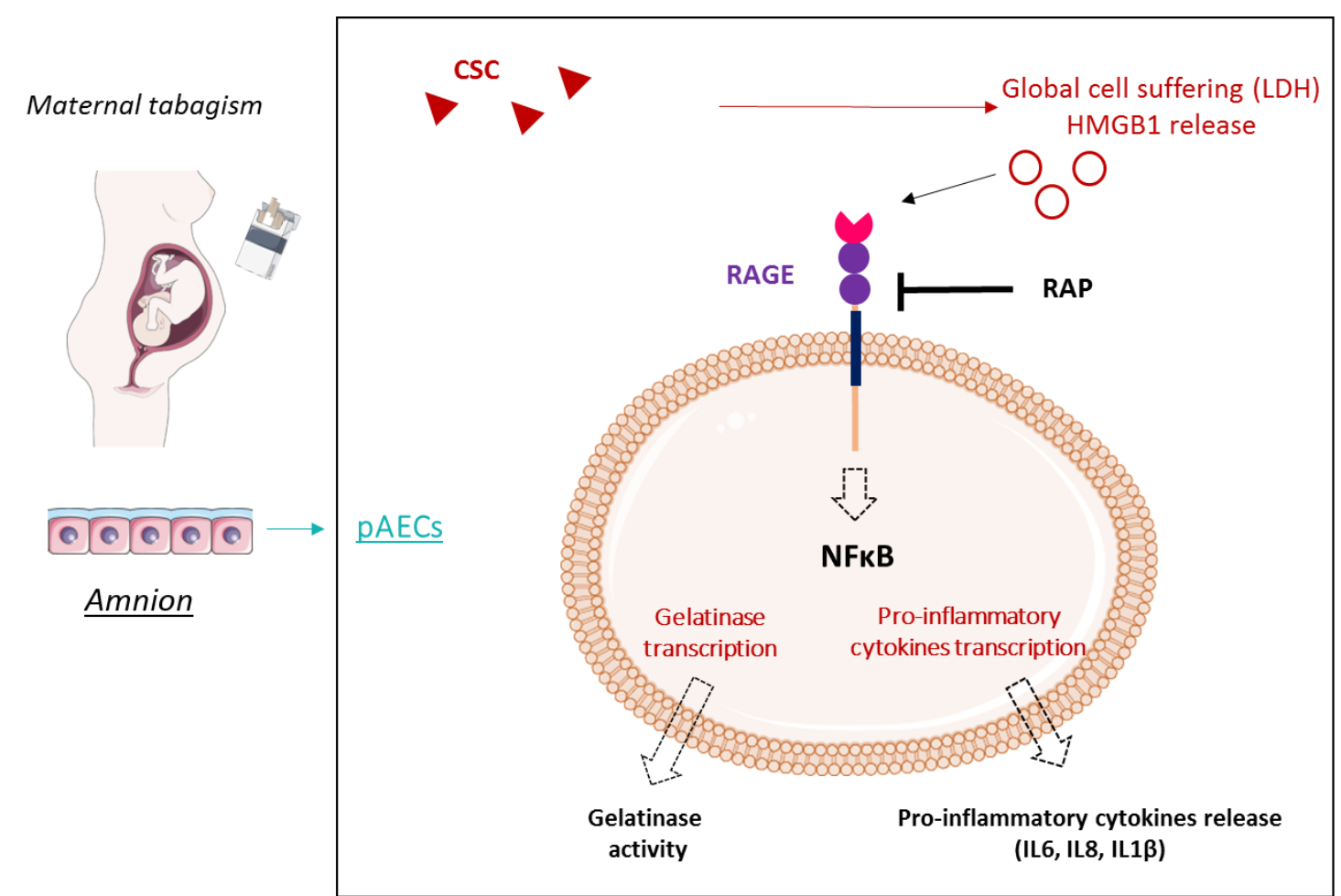

Figure 6. Maternal tabagism model of negative consequences on amniotic cells by the induction of RAGE-dependent sterile inflammation and gelatinase activity. Sterile inflammation is a key phenomenon of FM weakening, not only in physiological rupture, but also in pPROM. Exposure to tobacco during pregnancy is a well-known risk factor of pPROM. We demonstrated here that CSC induces an in vitro HMGB1 release by the amnion, a well-known danger signal. Then, this alarmin, a major ligand of RAGE, can induce a pro-inflammatory response (NF- $\mathrm{B}$ activation and cytokine production) through the RAGE pathway in amniotic epithelial cells, which suggests the essential role of RAGE in FM rupture and pPROM. smart.servier.com was used to create the figure.

\section{Materials and Methods}

\subsection{Chemicals}

CSC (20 mg/mL in dimethylsulfoxyde (DMSO)) was purchased from Kentucky Tobacco \& Research Development Center (Lexington, KY, USA), and DMSO was purchased from Sigma-Aldrich (Saint-Quentin-Fallavier, France). RAGE Antagonist Peptide (RAP) (Cat $\mathrm{N}^{\circ} 553031$, Calbiochem ${ }^{\circledR}, 5 \mathrm{mg} / \mathrm{mL}$ in water) was obtained from Sigma-Aldrich (SaintQuentin-Fallavier, France). The cell culture medium and antibiotics (streptomycin, penicillin, and amphotericin B) were obtained from Fisher Scientific ${ }^{\mathrm{TM}}$ (Illkirch-Graffenstaden, France), and fetal bovine serum was purchased from Eurobio Scientific (Les Ulis, France). Collagen I ( $3 \mathrm{mg} / \mathrm{mL}$ ) was obtained from Stemcell Technologies (Grenoble, France). Superscript IV First-Strand-Synthesis System, Taq DNA polymerase recombinant (10342020), and Pierce BCA Protein Assay Kit (23225) were obtained from Fisher Scientific ${ }^{\mathrm{TM}}$ (IllkirchGraffenstaden, France) and SYBR Green from Roche (Meylan, France).

\subsection{Tissue Collection}

Full-term FMs were collected from non-smoking women with healthy pregnancies from vaginal or scheduled cesarean deliveries (e.g., breech presentation or scarred wombs) 
(Centre Hospitalier Universitaire Estaing, Clermont-Ferrand, France) after obtaining informed consent. Gestational ages were $39.04 \pm 0.38$ weeks, the mean maternal ages were $31.26 \pm 3.79$ years, and the maternal body mass index was $26.33 \pm 4.14$. The selected FMs were collected from singleton pregnant women who had no underlying diseases, gestational diabetes, or clinical chorioamnionitis (defined by maternal fever, uterine tenderness, and/or purulent amniotic fluid). The research protocol was approved by the institutional regional ethics committee (DC-2008-558).

\subsection{Tissue and Cell Culture}

Explants (dissociated) of the amnion and choriodecidua were cultivated $\left(5 \% \mathrm{CO}_{2}\right.$; $95 \%$ humidified air; $37^{\circ} \mathrm{C}$ ) in Dulbecco's modified eagle medium/nutrient mixture F-12 (DMEMF12- GlutaMAX, Gibco ${ }^{\mathrm{TM}}$, Illkirch-Graffenstaden, France), supplemented with $10 \%$ FBS, $100 \mathrm{mg} / \mathrm{mL}$ of streptomycin, $100 \mathrm{U} / \mathrm{mL}$ of ampicillin, and $25 \mathrm{mg} / \mathrm{mL}$ amphotericin $\mathrm{B}\left(\mathrm{Gibco}^{\mathrm{TM}}\right.$, Illkirch-Graffenstaden, France). Explants were $2 \mathrm{~cm}^{2}$ in size, cut $2 \mathrm{~cm}$ away from the preplacental edge, and prepared by dissection. Tissue fragments were transferred (in duplicate) to 24-well culture plates and incubated in the cell media at $37^{\circ} \mathrm{C}$ for $1 \mathrm{~h}$ before treatment.

pAECs were cultivated under standard conditions $\left(5 \% \mathrm{CO}_{2} ; 95 \%\right.$ humidified air; $\left.37^{\circ} \mathrm{C}\right)$ in Dulbecco's Modified Eagle Medium F-12 nutrient mixture (DMEM-F12- GlutaMAX) supplemented with $10 \% \mathrm{FBS}, 100 \mu \mathrm{g} / \mathrm{mL} / \mathrm{mL}$ of streptomycin, $100 \mathrm{U} / \mathrm{mL}$ of ampicillin, and $25 \mu \mathrm{g} / \mathrm{mL}$ amphotericin B. As previously validated, the isolation of pAECs was conducted in three trypsinization steps $(10,20$, and $30 \mathrm{~min})$, followed by the scraping of the amnion [52]. Cells were filtered to remove the collagen, centrifuged for $5 \mathrm{~min}$ at $1000 \mathrm{rpm}$, and grown on culture dishes coated with collagen I (1/50 dilution in PBS 1X) in complete media.

\subsection{Tissue and Cell Treatment}

Cells or explants were treated with DMSO or CSC (respectively 100 or $500 \mu \mathrm{g} / \mathrm{mL}$ ) in the absence or presence of RAP $(12.7$ or $63.6 \mu \mathrm{g} / \mathrm{mL})$ for $24 \mathrm{~h}, 48 \mathrm{~h}$, or $72 \mathrm{~h}$ (with treatment renewal at $48 \mathrm{~h}$ ).

\subsection{Global Cellular Distress Determination}

To evaluate the impact of treatment on global cell suffering, the release of the intracellular enzyme lactate dehydrogenase (LDH) into the cell media was quantified on an automate (Siemens Vista, Paris, France) using an enzymatic assay, following the manufacturer's recommendations.

\subsection{Western Blot Analysis of HMGB1 Release}

First, the supernatants of the treated explants were concentrated into $2 \mathrm{kDa}$ centrifugal filter units (Vivacon ${ }^{\circledR} 500$, Sartorius, Aubagne, France) for protein concentration and purification, following the manufacturer's instructions. Then, the proteins were resolved on a $4-15 \%$ Mini-PROTEAN ${ }^{\circledR}$ TGX Stain-Free ${ }^{\mathrm{TM}}$ Precast Gel (Bio-Rad, Marnes-la-Coquette, France) to perform total protein normalization [53]. Before the transfer, stain-free imaging was completed. This technology utilizes a proprietary trihalo compound to enhance natural protein fluorescence by covalently binding to tryptophan residues with brief UV activation (Bio-Rad, Marnes-la-Coquette, France). Then, the transfer was performed on a nitrocellulose membrane (Bio-Rad, Marnes-la-Coquette, France) and saturated for more than 90 min with 5\% skimmed milk in a Tris-Buffered Saline (TBS) 1X. HMGB1 primary antibody (1/10000, ab79823, Abcam, Paris, France) was diluted in 5\% skimmed milk-TBS 1X-TWEEN ${ }^{\circledR} 200.1 \%$ and incubated overnight at $4{ }^{\circ} \mathrm{C}$. The next day, the membrane was washed three times with TBS/TWEEN ${ }^{\circledR} 200.1 \%$ and incubated at room temperature with a horseradish peroxidase coupled with a secondary antibody anti-rabbit (1/10000, BI 2407, Abliance, Compiègne, France) for $90 \mathrm{~min}$. The revelation was completed using an ECL Clarity kit for a western blot on the ChemiDoc ${ }^{\mathrm{TM}}$ imaging system (Bio-Rad, Marnes-la- 
Coquette, France). Image Lab Software (Bio-Rad, Marnes-la-Coquette, France) was used for quantification. Results are expressed as a mean of at least three independent experiments.

\subsection{RT-PCR and Quantitative RT-PCR on Explants and Cells}

After the disruption step with a Precellys homogenizer (Bertin Technologies, Montignyle-Bretonneux, France) using ceramic beads (KT03961, Ozyme, Saint-Cyr-l'École, France), the total number of RNAs were extracted from the explants using RNAzol ${ }^{\circledR}$ RT (RN190, Molecular Research Center, Cincinnati, OH, USA). For the cells, RNA extraction was performed with NucleoSpin RNA (REF 740955.50, Macherey-Nagel, Hoerdt, France), following the manufacturer's instructions. Reverse transcription was realized on $1 \mu \mathrm{g}$ of RNA using a Superscript IV First-Strand-Synthesis System for reverse transcription polymerase chain reaction (RT-PCR). PCR experiments were performed using specific oligonucleotides (Table 1).

Table 1. Forward and reverse primer sequences used for RT-PCR and RT-qPCR amplification of human genes.

\begin{tabular}{|c|c|c|c|}
\hline Gene & Sequence $5^{\prime}-3^{\prime}$ (F: Forward, r: Reverse) & Product Size (bp) & $\begin{array}{c}\text { Annealing } \\
\text { Temperature }\left({ }^{\circ} \mathrm{C}\right)\end{array}$ \\
\hline$h s R A G E$ & $\begin{array}{l}\text { F: TGTGCTGATCCTCCCTGAGA } \\
\text { R: TGCAGTTGGCCCCTCCTCG }\end{array}$ & 139 & 61 \\
\hline$h s 36 B 4$ & $\begin{array}{l}\text { F: AGGCTTTAGGTATCACCACT } \\
\text { R: GCAGAGTTTCCTCTGTGATA }\end{array}$ & 219 & 61 \\
\hline hsRSP17 & $\begin{array}{l}\text { F: TGCGAGGAGATCGCCATTATC } \\
\text { R: AAGGCTGAGACCTCAGGAAC }\end{array}$ & 169 & 61 \\
\hline$h s M y D 88$ & $\begin{array}{l}\text { F: GCAGGAGGAGGCTGAGAAGC } \\
\text { R: CGGATCATCTCCTGCACAAACT }\end{array}$ & 177 & 66 \\
\hline hsTIRAP & $\begin{array}{l}\text { F: AAGTACCAGATGCTGCAGGCC } \\
\text { R: AGTGTCAACTGAGTGTCTGCAG }\end{array}$ & 200 & 66 \\
\hline hsDia-1 & $\begin{array}{l}\text { F: AGAGCCACACTTCCTTTCCATC } \\
\text { R: TCAATCTCAATCTGGAGGTGCC }\end{array}$ & 167 & 66 \\
\hline hsIL6 & $\begin{array}{l}\text { F: AATGAGGAGACTTGCCTGGTG } \\
\text { R: AGGAACTGGATCAGGACTTTTG }\end{array}$ & 143 & 61 \\
\hline hsIL8 & $\begin{array}{l}\text { F: TGATTTCTGCAGCTCTGTGTG } \\
\text { R: TCTGTGTTGGCGCAGTGTGG }\end{array}$ & 154 & 61 \\
\hline$h s I L 1 \beta$ & $\begin{array}{l}\text { F: AATCTCCGACCACCACTACAG } \\
\text { R: TCCCATGTGTCGAAGAAGATAG }\end{array}$ & 174 & 62 \\
\hline hsMMPg & $\begin{array}{l}\text { F: ATTGACGACGCCTTTGCCCG } \\
\text { R: ATGGGCGTCTCCCTGAATGC }\end{array}$ & 201 & 61 \\
\hline$h s M M P 2$ & $\begin{array}{l}\text { F: AGCTCATCGCAGATGCCTGG } \\
\text { R: AAGGGCCTGTGGGAGCCAG }\end{array}$ & 199 & 61 \\
\hline
\end{tabular}

The results were analyzed on a $2 \%$ agarose gel. Gene expression was assessed by quantitative RT-PCR (RT-qPCR), which was performed using LightCycler ${ }^{\circledR} 480$ SYBR Green I Master (Roche, Meylan, France). Transcript quantification was performed in duplicate on at least four independent experiments. Standard curves were used to quantify the amount of amplified transcripts. Results were normalized to the geometric mean of the human housekeeping genes RPL0 (36b4) and RPS17 (acidic ribosomal phosphoprotein P0 and ribosomal protein S17, respectively), as recommended by the MIQE guidelines [54].

\subsection{Cytokine Release Assay}

The release of IL1 $\beta$, IL6, and IL8 in the culture media was quantified after $48 \mathrm{~h}$ of CSC treatment using automated multiplex immunoassays on Ella ${ }^{\mathrm{TM}}$ (San Jose, CA, USA). Finally, cytokine concentrations were normalized to total protein concentration, and the fold change "treated/control" was reported. 


\subsection{Immunofluorescence}

pAECs grown on collagen type I-coated coverslips in six-well plates were washed with PBS 1X before fixation with 4\% paraformaldehyde (Electron Microscopy Sciences, 15710; can be stored at $-80^{\circ} \mathrm{C}$ ). After permeabilization in PBS 1X/FBS 10\%/Triton $0.1 \%$ for more than $90 \mathrm{~min}$, the primary antibody against RAGE (1/1000, ab37647, Abcam, Paris, France), HMGB1 (1/400, ab79823, Abcam, Paris, France), Myd88 (1/250, ab133739, Abcam, Paris, France), TIRAP (1/100, ab17218, Abcam, Paris, France), Diaphanous-1 (1/400, ab11173, Abcam, Paris, France), and p65 NF- $к B$ (1/400, 8242, Cell signaling, Saint-Cyr-L'Ecole, France) was applied overnight at $4{ }^{\circ} \mathrm{C}$. After three washes in the permeabilization buffer, the secondary antibody, anti-rabbit Alexa Fluor ${ }^{\circledR} 488$ (1/1000, A21206, Life Technologies, Villebon-Sur-Yvette, France), was incubated for $2 \mathrm{~h}$ at room temperature. Slides were washed three times in PBS 1X and incubated with Hoescht (15 min, dilution in PBS 1X 1/10,000; bisBenzimide H, 33258, Sigma-Aldrich, Saint-Quentin-Fallavier, France). Finally, slides were mounted with CitiFluor ${ }^{\mathrm{TM}}$ Tris-MWL 4-88 (Electron Microscopy Science, Hatfield, PA, USA) and examined under a Zeiss LSM800 Airyscan for cells. For the negative controls, incubation without the primary antibody was performed.

\subsection{NFאB Gene Reporter Luciferase Assay}

pAECs grown at $80 \%$ confluence in six-well plates were co-transfected with $500 \mathrm{ng}$ of pNF-kB-Firefly Luciferase plasmid (Agilent) expressing luciferase under control of NF- $k B$ responsive elements and $50 \mathrm{ng}$ of pRL-TK-Renilla-Luciferase expression vector (Promega, Charbonnières-les-Bains, France), which allowed the normalization of the transfection efficiency. Transfections were performed using $3.75 \mu \mathrm{L}$ of Lipofectamine 3000 (Fisher Scientific, Illkirch-Graffenstaden, France) and $2 \mu \mathrm{L}$ of reagent P3000 (Fisher Scientific, IllkirchGraffenstaden, France) per well. Cells were treated with DMSO or CSC $(100 \mu \mathrm{g} / \mathrm{mL})$, whether combined or not with RAP $(12.7 \mu \mathrm{g} / \mathrm{mL}), 24 \mathrm{~h}$ after the transfection for $48 \mathrm{~h}$. Firefly and Renilla luciferase activities were then measured with a FB12 luminometer (Berthold, Thoiry, France) in the cellular extracts using the dual-luciferase reporter assay system (Promega, Charbonnières-les-Bains, France), according to the manufacturer's instructions. This experiment was repeated three times (each condition in duplicate).

\subsection{Gelatinase Activity Measurement}

Gelatinase activity was measured on a cell culture media (1/500 diluted) using a gelatinase activity assay kit (MAK348, Sigma-Aldrich, Saint-Louis, MI, USA), following the manufacturer's instructions. Fluorescence was measured in kinetic mode at $37^{\circ} \mathrm{C}$ for two hours on a FlexStation microplate reader (Molecular devices, San Jose, CA, USA).

\subsection{Statistical Analysis}

The data expressed as the mean \pm standard error of the mean are an average of duplicates or triplicates of at least three independent experiments. Since the results did not follow normal distribution (consequence of the small $\mathrm{N}$ ), the comparison of means was performed by non-parametric tests (Mann-Whitney t-test or one-way ANOVA KruskalWallis test, followed by multiple comparison with Dunn's correction for the comparison of more than two groups) using PRISM software 5.02 (GraphPad Software Inc., San Diego, CA, USA). For all studies, values were considered significantly different at $p<0.05\left(^{*}\right)$, $p<0.01\left(^{* *}\right)$, and $p<0.001{ }^{(* *)}$. Mean ratio (treated/control groups) values are indicated in the results part.

Supplementary Materials: The following are available online at https:/ / www.mdpi.com/article/ $10.3390 /$ ijms22158345/s1. 
Author Contributions: H.C. designed and performed the experiments and wrote the manuscript. J.D. participated in the ELLA assays, R.M.-Q. performed lactate dehydrogenase assays, and C.B. assisted in some experiments. D.G. allowed H.C. to obtain human fetal membranes from patients in the Centre Hospitalier Universitaire Estaing (Clermont-Ferrand, France). V.S. and L.B. supervised the project and wrote the manuscript. All authors have read and agreed to the published version of the manuscript.

Funding: H.C. was funded by a French ministerial grant.

Institutional Review Board Statement: The study was conducted according to the guidelines of the Declaration of Helsinki and approved by the Institutional Regional Ethics Committee of ClermontFerrand Sud-Est VI (Personal Protection Committee) (DC-2008-558).

Informed Consent Statement: Patient consent was waived due to the French bioethics law which identified the placenta and the fetal membranes as "care activity waste" until the delivery, thus no consent statement is required from the mother.

Conflicts of Interest: The authors declare no conflict of interest.

\section{References}

1. Nabet, C.; Lelong, N.; Ancel, P.-Y.; Saurel-Cubizolles, M.-J.; Kaminski, M. Smoking during Pregnancy According to Obstetric Complications and Parity: Results of the EUROPOP Study. Eur. J. Epidemiol. 2007, 22, 715-721. [CrossRef]

2. Lewis, J.; Hirschi, K.; Arroyo, J.; Bikman, B.; Kooyman, D.; Reynolds, P. Plausible Roles for RAGE in Conditions Exacerbated by Direct and Indirect (Secondhand) Smoke Exposure. Int. J. Mol. Sci. 2017, 18, 652. [CrossRef]

3. Wrześniak, M.; Kepinska, M.; Królik, M.; Milnerowicz, H. The Influence of Tobacco Smoke on Protein and Metal Levels in the Serum of Women during Pregnancy. PLoS ONE 2016, 11, e0161342. [CrossRef]

4. Witt, S.H.; Frank, J.; Gilles, M.; Lang, M.; Treutlein, J.; Streit, F.; Wolf, I.A.C.; Peus, V.; Scharnholz, B.; Send, T.S.; et al. Impact on Birth Weight of Maternal Smoking throughout Pregnancy Mediated by DNA Methylation. BMC Genom. 2018, 19, 290. [CrossRef] [PubMed]

5. Rogers, J.M. Tobacco and Pregnancy. Reprod. Toxicol. 2009, 28, 152-160. [CrossRef] [PubMed]

6. von Chamier, M.; Reyes, L.; Hayward, L.F.; Brown, M.B. Nicotine Induces Maternal and Fetal Inflammatory Responses Which Predispose Intrauterine Infection Risk in a Rat Model. Nicotine Tob. Res. 2021, natb080. [CrossRef] [PubMed]

7. Kim, Y.-H.; An, Y.-J.; Jo, S.; Lee, S.-H.; Lee, S.J.; Choi, S.-J.; Lee, K. Comparison of Volatile Organic Compounds between Cigarette Smoke Condensate (CSC) and Extract (CSE) Samples. Environ. Health Toxicol. 2018, 33, e2018012. [CrossRef]

8. Polettini, J.; Richardson, L.S.; Menon, R. Oxidative Stress Induces Senescence and Sterile Inflammation in Murine Amniotic Cavity. Placenta 2018, 63, 26-31. [CrossRef] [PubMed]

9. Jin, J.; Richardson, L.; Sheller-Miller, S.; Zhong, N.; Menon, R. Oxidative Stress Induces P38MAPK-Dependent Senescence in the Feto-Maternal Interface Cells. Placenta 2018, 67, 15-23. [CrossRef] [PubMed]

10. Bredeson, S.; Papaconstantinou, J.; Deford, J.H.; Kechichian, T.; Syed, T.A.; Saade, G.R.; Menon, R. HMGB1 Promotes a P38MAPK Associated Non-Infectious Inflammatory Response Pathway in Human Fetal Membranes. PLoS ONE 2014, 9, e113799. [CrossRef] [PubMed]

11. Sheller-Miller, S.; Urrabaz-Garza, R.; Saade, G.; Menon, R. Damage-Associated Molecular Pattern Markers HMGB1 and Cell-Free Fetal Telomere Fragments in Oxidative-Stressed Amnion Epithelial Cell-Derived Exosomes. J. Reprod. Immunol. 2017, 123, 3-11. [CrossRef] [PubMed]

12. Menon, R.; Peltier, M.R. Novel Insights into the Regulatory Role of Nuclear Factor (Erythroid-Derived 2)-Like 2 in Oxidative Stress and Inflammation of Human Fetal Membranes. Int. J. Mol. Sci. 2020, 21, 6139. [CrossRef] [PubMed]

13. Menon, R.; Fortunato, S.J.; Yu, J.; Milne, G.L.; Sanchez, S.; Drobek, C.O.; Lappas, M.; Taylor, R.N. Cigarette Smoke Induces Oxidative Stress and Apoptosis in Normal Term Fetal Membranes. Placenta 2011, 32, 317-322. [CrossRef]

14. Rouzaire, M.; Comptour, A.; Belville, C.; Bouvier, D.; Sapin, V.; Gallot, D.; Blanchon, L. Cigarette Smoke Condensate Affects the Retinoid Pathway in Human Amnion. Placenta 2017, 58, 98-104. [CrossRef]

15. Cerami, C.; Founds, H.; Nicholl, I.; Mitsuhashi, T.; Giordano, D.; Vanpatten, S.; Lee, A.; Al-Abed, Y.; Vlassara, H.; Bucala, R.; et al. Tobacco Smoke Is a Source of Toxic Reactive Glycation Products. Proc. Natl. Acad. Sci. USA 1997, 94, 13915-13920. [CrossRef]

16. Nicholl, I.D.; Bucala, R. Advanced Glycation Endproducts and Cigarette Smoking. Cell Mol. Biol. 1998, 44, 1025-1033.

17. Tsai, C.-Y.; Chou, H.-C.; Chen, C.-M. Perinatal Nicotine Exposure Alters Lung Development and Induces HMGB1-RAGE Expression in Neonatal Mice. Birth Defects Res. 2020, 113, 570-578. [CrossRef]

18. Railwah, C.; Lora, A.; Zahid, K.; Goldenberg, H.; Campos, M.; Wyman, A.; Jundi, B.; Ploszaj, M.; Rivas, M.; Dabo, A.; et al. Cigarette Smoke Induction of S100A9 Contributes to Chronic Obstructive Pulmonary Disease. Am. J. Physiol. Lung Cell. Mol. Physiol. 2020, 319, L1021-L1035. [CrossRef]

19. Zhang, S.-P.; Wu, Y.-W.; Wu, Z.-Z.; Liu, H.-Y.; Nie, J.-H.; Tong, J. Up-Regulation of RAGE and S100A6 in Rats Exposed to Cigarette Smoke. Environ. Toxicol. Pharmacol. 2009, 28, 259-264. [CrossRef] 
20. Wood, T.T.; Winden, D.R.; Marlor, D.R.; Wright, A.J.; Jones, C.M.; Chavarria, M.; Rogers, G.D.; Reynolds, P.R. Acute Secondhand Smoke-Induced Pulmonary Inflammation Is Diminished in RAGE Knockout Mice. Am. J. Physiol. Lung Cell. Mol. Physiol. 2014, 307, L758-L764. [CrossRef] [PubMed]

21. Lee, H.; Lee, J.; Hong, S.-H.; Rahman, I.; Yang, S.-R. Inhibition of RAGE Attenuates Cigarette Smoke-Induced Lung Epithelial Cell Damage via RAGE-Mediated Nrf2/DAMP Signaling. Front. Pharmacol. 2018, 9, 684. [CrossRef]

22. Wolf, L.; Herr, C.; Niederstraßer, J.; Beisswenger, C.; Bals, R. Receptor for Advanced Glycation Endproducts (RAGE) Maintains Pulmonary Structure and Regulates the Response to Cigarette Smoke. PLoS ONE 2017, 12, e0180092. [CrossRef]

23. Prasad, K.; Dhar, I.; Caspar-Bell, G. Role of Advanced Glycation End Products and Its Receptors in the Pathogenesis of Cigarette Smoke-Induced Cardiovascular Disease. Int. J. Angiol. 2015, 24, 75-80. [CrossRef] [PubMed]

24. Lewis, J.B.; Mejia, C.; Jordan, C.; Monson, T.D.; Bodine, J.S.; Dunaway, T.M.; Egbert, K.M.; Lewis, A.L.; Wright, T.J.; Ogden, K.C.; et al. Inhibition of the Receptor for Advanced Glycation End-Products (RAGE) Protects from Secondhand Smoke (SHS)-Induced Intrauterine Growth Restriction IUGR in Mice. Cell Tissue Res. 2017, 370, 513-521. [CrossRef] [PubMed]

25. Xie, J.; Méndez, J.D.; Méndez-Valenzuela, V.; Aguilar-Hernández, M.M. Cellular Signalling of the Receptor for Advanced Glycation End Products (RAGE). Cell. Signal. 2013, 25, 2185-2197. [CrossRef] [PubMed]

26. Barbezier, N.; Tessier, F.J.; Chango, A. Receptor of advanced glycation endproducts RAGE/AGER: An integrative view for clinical applications. Ann. Biol. Clin. 2014, 72, 669-680. [CrossRef] [PubMed]

27. Sakaguchi, M.; Kinoshita, R.; Putranto, E.W.; Ruma, I.M.W.; Sumardika, I.W.; Youyi, C.; Tomonobu, N.; Yamamoto, K.-I.; Murata, H. Signal Diversity of Receptor for Advanced Glycation End Products. Acta Med. Okayama 2017, 71, 459-465. [CrossRef]

28. Sakaguchi, M.; Murata, H.; Yamamoto, K.; Ono, T.; Sakaguchi, Y.; Motoyama, A.; Hibino, T.; Kataoka, K.; Huh, N. TIRAP, an Adaptor Protein for TLR2/4, Transduces a Signal from RAGE Phosphorylated upon Ligand Binding. PLoS ONE 2011, 6, e23132. [CrossRef] [PubMed]

29. Hudson, B.I.; Kalea, A.Z.; del Mar Arriero, M.; Harja, E.; Boulanger, E.; D'Agati, V.; Schmidt, A.M. Interaction of the RAGE Cytoplasmic Domain with Diaphanous-1 Is Required for Ligand-Stimulated Cellular Migration through Activation of Rac1 and Cdc42. J. Biol. Chem. 2008, 283, 34457-34468. [CrossRef] [PubMed]

30. Kumar, V.; Fleming, T.; Terjung, S.; Gorzelanny, C.; Gebhardt, C.; Agrawal, R.; Mall, M.A.; Ranzinger, J.; Zeier, M.; Madhusudhan, T.; et al. Homeostatic Nuclear RAGE-ATM Interaction Is Essential for Efficient DNA Repair. Nucleic Acids Res. 2017, 45, 10595-10613. [CrossRef]

31. Williams, M.A.; Mittendorf, R.; Stubblefield, P.G.; Lieberman, E.; Schoenbaum, S.C.; Monson, R.R. Cigarettes, Coffee, and Preterm Premature Rupture of the Membranes. Am. J. Epidemiol. 1992, 135, 895-903. [CrossRef]

32. England, M.; Benjamin, A.; Abenhaim, H. Increased Risk of Preterm Premature Rupture of Membranes at Early Gestational Ages among Maternal Cigarette Smokers. Am. J. Perinatol. 2013, 30, 821-826. [CrossRef]

33. Shea, A.K.; Steiner, M. Cigarette Smoking during Pregnancy. Nicotine Tob. Res. 2008, 10, 267-278. [CrossRef]

34. Pouwels, S.D.; Zijlstra, G.J.; van der Toorn, M.; Hesse, L.; Gras, R.; Ten Hacken, N.H.T.; Krysko, D.V.; Vandenabeele, P.; de Vries, M.; van Oosterhout, A.J.M.; et al. Cigarette Smoke-Induced Necroptosis and DAMP Release Trigger Neutrophilic Airway Inflammation in Mice. Am. J. Physiol. Lung Cell. Mol. Physiol. 2016, 310, L377-L386. [CrossRef] [PubMed]

35. Pouwels, S.D.; Hesse, L.; Faiz, A.; Lubbers, J.; Bodha, P.K.; ten Hacken, N.H.T.; van Oosterhout, A.J.M.; Nawijn, M.C.; Heijink, I.H. Susceptibility for Cigarette Smoke-Induced DAMP Release and DAMP-Induced Inflammation in COPD. Am. J. Physiol. Lung Cell. Mol. Physiol. 2016, 311, L881-L892. [CrossRef]

36. Sharma, A.; Kaur, S.; Sarkar, M.; Sarin, B.C.; Changotra, H. The AGE-RAGE Axis and RAGE Genetics in Chronic Obstructive Pulmonary Disease. Clin. Rev. Allergy Immunol. 2020, 60, 244-258. [CrossRef] [PubMed]

37. Choltus, H.; Lavergne, M.; Belville, C.; Gallot, D.; Minet-Quinard, R.; Durif, J.; Blanchon, L.; Sapin, V. Occurrence of a RAGEMediated Inflammatory Response in Human Fetal Membranes. Front. Physiol. 2020, 11, 581. [CrossRef] [PubMed]

38. Filipovich, Y.; Lu, S.-J.; Akira, S.; Hirsch, E. The Adaptor Protein MyD88 Is Essential for E Coli-Induced Preterm Delivery in Mice. Am. J. Obstet. Gynecol. 2009, 200, 93.e1-93.e8. [CrossRef]

39. Lee, Y.; Allport, V.; Sykes, A.; Lindstrom, T.; Slater, D.; Bennett, P. The Effects of Labour and of Interleukin 1 Beta upon the Expression of Nuclear Factor Kappa B Related Proteins in Human Amnion. Mol. Hum. Reprod. 2003, 9, 213-218. [CrossRef]

40. Sheller-Miller, S.; Radnaa, E.; Yoo, J.-K.; Kim, E.; Choi, K.; Kim, Y.; Kim, Y.N.; Richardson, L.; Choi, C.; Menon, R. Exosomal Delivery of NF-KB Inhibitor Delays LPS-Induced Preterm Birth and Modulates Fetal Immune Cell Profile in Mouse Models. Sci. Adv. 2021, 7, eabd3865. [CrossRef]

41. Takbiri Osgoei, L.; Parivar, K.; Ebrahimi, M.; Mortaz, E. Nicotine Modulates the Release of Inflammatory Cytokines and Expression of TLR2, TLR4 of Cord Blood Mononuclear Cells. Iran. J. Allergy Asthma Immunol. 2018, 17, 372-378. [CrossRef] [PubMed]

42. Cheng, Y.; Wang, D.; Wang, B.; Li, H.; Xiong, J.; Xu, S.; Chen, Q.; Tao, K.; Yang, X.; Zhu, Y.; et al. HMGB1 Translocation and Release Mediate Cigarette Smoke-Induced Pulmonary Inflammation in Mice through a TLR4/MyD88-Dependent Signaling Pathway. MBoC 2017, 28, 201-209. [CrossRef]

43. Allam, V.S.R.R.; Faiz, A.; Lam, M.; Rathnayake, S.N.H.; Ditz, B.; Pouwels, S.D.; Brandsma, C.-A.; Timens, W.; Hiemstra, P.S.; Tew, G.W.; et al. RAGE and TLR4 Differentially Regulate Airway Hyperresponsiveness: Implications for COPD. Allergy 2020, 76, 1123-1135. [CrossRef] 
44. Winden, D.R.; Barton, D.B.; Betteridge, B.C.; Bodine, J.S.; Jones, C.M.; Rogers, G.D.; Chavarria, M.; Wright, A.J.; Jergensen, Z.R.; Jimenez, F.R. Antenatal Exposure of Maternal Secondhand Smoke (SHS) Increases Fetal Lung Expression of RAGE and Induces RAGE-Mediated Pulmonary Inflammation. Respir. Res. 2014, 15, 129. [CrossRef] [PubMed]

45. Kim, H.J.; Park, K.H.; Kim, Y.M.; Joo, E.; Ahn, K.; Shin, S. A Protein Microarray Analysis of Amniotic Fluid Proteins for the Prediction of Spontaneous Preterm Delivery in Women with Preterm Premature Rupture of Membranes at 23 to 30 Weeks of Gestation. PLoS ONE 2020, 15, e0244720. [CrossRef] [PubMed]

46. Romero, R.; Chaiworapongsa, T.; Espinoza, J.; Gomez, R.; Yoon, B.H.; Edwin, S.; Mazor, M.; Maymon, E.; Berry, S. Fetal Plasma MMP-9 Concentrations Are Elevated in Preterm Premature Rupture of the Membranes. Am. J. Obstet. Gynecol. 2002, 187, 1125-1130. [CrossRef]

47. Ferrand, P.E.; Parry, S.; Sammel, M.; Macones, G.A.; Kuivaniemi, H.; Romero, R.; Strauss, J.F. A Polymorphism in the Matrix Metalloproteinase-9 Promoter Is Associated with Increased Risk of Preterm Premature Rupture of Membranes in African Americans. Mol. Hum. Reprod. 2002, 8, 494-501. [CrossRef]

48. Macarie, R.D.; Vadana, M.; Ciortan, L.; Tucureanu, M.M.; Ciobanu, A.; Vinereanu, D.; Manduteanu, I.; Simionescu, M.; Butoi, E. The Expression of MMP-1 and MMP-9 Is up-Regulated by Smooth Muscle Cells after Their Cross-Talk with Macrophages in High Glucose Conditions. J. Cell. Mol. Med. 2018, 22, 4366-4376. [CrossRef]

49. Yan, W.; Fan, W.; Chen, C.; Wu, Y.; Fan, Z.; Chen, J.; Chen, Z.; Chen, H. IL-15 up-Regulates the MMP-9 Expression Levels and Induces Inflammatory Infiltration of Macrophages in Polymyositis through Regulating the NF-KB Pathway. Gene 2016, 591, 137-147. [CrossRef]

50. Sindhu, S.; Al-Roub, A.; Koshy, M.; Thomas, R.; Ahmad, R. Palmitate-Induced MMP-9 Expression in the Human Monocytic Cells Is Mediated through the TLR4-MyD88 Dependent Mechanism. Cell. Physiol. Biochem. 2016, 39, 889-900. [CrossRef]

51. Dwir, D.; Giangreco, B.; Xin, L.; Tenenbaum, L.; Cabungcal, J.-H.; Steullet, P.; Goupil, A.; Cleusix, M.; Jenni, R.; Chtarto, A.; et al. MMP9/RAGE Pathway Overactivation Mediates Redox Dysregulation and Neuroinflammation, Leading to Inhibitory/Excitatory Imbalance: A Reverse Translation Study in Schizophrenia Patients. Mol. Psychiatry 2020, 25, 2889-2904. [CrossRef] [PubMed]

52. Bouvier, D.; Rouzaire, M.; Marceau, G.; Prat, C.; Pereira, B.; Lemarié, R.; Deruelle, P.; Fajardy, I.; Gallot, D.; Blanchon, L.; et al. Aquaporins and Fetal Membranes From Diabetic Parturient Women: Expression Abnormalities and Regulation by Insulin. J. Clin. Endocrinol. Metab. 2015, 100, E1270-E1279. [CrossRef]

53. Gilda, J.E.; Gomes, A.V. Stain-Free Total Protein Staining Is a Superior Loading Control to $\beta$-Actin for Western Blots. Anal. Biochem. 2013, 440, 186-188. [CrossRef] [PubMed]

54. Bustin, S.A.; Benes, V.; Garson, J.A.; Hellemans, J.; Huggett, J.; Kubista, M.; Mueller, R.; Nolan, T.; Pfaffl, M.W.; Shipley, G.L.; et al. The MIQE Guidelines: Minimum Information for Publication of Quantitative Real-Time PCR Experiments. Clin. Chem. 2009, 55, 611-622. [CrossRef] [PubMed] 